\title{
Martial arts pedagogies and practice: A report on the contributions to coaching knowledge
}

\author{
George JENNINGS* \\ Cardiff Metropolitan University (UK)
}

Recepción: 07/10/2017; Aceptación: 26/11/2017; Publicación: 30/11/2017.

\begin{abstract}
The $4^{\text {th }}$ International Coaching Conference held at Cardiff Metropolitan University, UK, showcased a range of studies concerning pedagogy in martial arts (MA). They varied in regards to their underpinning discipline, theory and method, but were united by a concern for enhancing practice in both pedagogy (the science) and pedagogies (the objects of study). One theoretical talk advocated a study of individual practices (techniques of the body and their corresponding methods) via praxiography in relation for a balanced, critical health pedagogy examining the duality of 'dark' and 'light' aspects. This in turn was applied by an emerging study looking at rapid weight loss practices in Judo and other combat sports that is beginning to scrutinise policies in order to regular this problem. Meanwhile, an investigation into the mental toughness of Karate practitioners uncovered similarly alarming findings on extreme training methods among veteran Welsh Karateka, while another study of a British context of Savate and Capoeira shared ways of studying MA pedagogies in their total form through traditional approach to ethnography. Together, these papers exemplify the increasing corpus of knowledge on teaching and learning in MA that could support that of coaching alongside sport and body pedagogy.
\end{abstract}

Keywords: Martial arts; pedagogy; practice; body pedagogies; coaching; praxiography.

\section{Pedagogías y práctica de las artes marciales: un informe sobre las contribuciones al conocimiento del coaching}

\section{Resumen}

La $4^{\text {th }}$ International Coaching Conference celebrada en la Cardiff Metropolitan University, Reino Unido, mostró diversos estudios sobre la pedagogía en artes marciales (AM). Diversos en cuanto a disciplinas, teorías y métodos subyacentes, pero unidos por el interés en mejorar la práctica tanto en la pedagogía (la ciencia) como en las pedagogías (los objetos de estudio). Una ponencia estudió las prácticas individuales (técnicas del cuerpo y sus métodos correspondientes) a través de la praxiografía, mediante una pedagogía crítica, equilibrando los aspectos "oscuros" y "claros" de las AM. Esto también fue considerado en un estudio emergente que analiza las pérdidas rápidas de peso realizadas en judo y en otros deportes de combate, que están empezando a considerar políticas para regular este problema. Asimismo, una investigación sobre la dureza mental de los practicantes de karate descubrió prácticas alarmantes de métodos de entrenamiento extremo entre karatekas galeses veteranos, mientras que otro estudio, de un contexto británico de práctica de savate y capoeira, compartió formas de estudiar las pedagogías de las AM de forma global mediante el enfoque tradicional de la etnografía. En conjunto, estos trabajos ejemplifican el creciente corpus de conocimiento existente sobre la enseñanza y el aprendizaje de las AM, que podría apoyar los propios corpus de conocimiento sobre el coaching y la pedagogía deportiva y corporal.

Palabras clave: Artes marciales; pedagogía; práctica; pedagogías corporales; entrenamiento; praxiografía.

\section{Pedagogias e práticas das artes marciais: um resumo sobre as contribuições para o conhecimento do coaching}

\section{Resumo}

$\mathrm{Na} 4^{\text {th }}$ International Coaching Conference, que teve lugar na Cardiff Metropolitan University, Reino Unido, foram apresentados diversos estudos sobre a pedagogia das artes marciais (AM). Foram diversos quanto as disciplinas, teorias e métodos subjacentes. Em todos, sobressaia a preocupação de melhorar a prática, tanto em pedagogia (a ciência), como nas pedagogias (os objetos de estudo). Uma das apresentações incidiu sobre as práticas individuais (técnicas do corpo e seus métodos correspondentes) através da praxiografia, mediante uma pedagogia crítica nos aspetos "obscuros" e "claros" das AM. Esto, por sua vez, foi aplicado por um estudo emergente que analisou as práticas de perda rápida de peso, que se observam no judo e em outros desportos de combate, de quem está a começar, e considerar políticas para regular este problema. Uma investigação sobre a dureza mental dos praticantes de karaté realçou práticas alarmantes similares de métodos de treino extremo entre karatecas veteranos gauleses, enquanto outro estudo, num contexto britânico de práticas de savate e capoeira, compartilhou formas de estudar as pedagogias das AM, de forma global, mediante o enfoque tradicional da etnografia. Em conjunto, estes trabalhos exemplificam o crescente corpus de conhecimento existente sobre o ensino e a aprendizagem das AM, que podem apoiar os próprios corpus de conhecimento sobre o coaching, a pedagogia desportiva e corporal.

Palavras-chave: Artes marciais; pedagogia; práticas corporais; treino; praxiografia.

*E-mail: gbjennings@cardiffmet.ac.uk 


\section{Introduction: The place of martial arts in coaching}

On the $6^{\text {th }}$ and $7^{\text {th }}$ September, 2017, The Cardiff School of Sport, then undergoing the transition of becoming the School of Sport and Health Science, at Cardiff Metropolitan University, hosted the $4^{\text {th }}$ International Coaching Conference. This biannual event aimed at providing a significant platform for networking and dissemination amongst the community of sports coaching scholars, students and practitioners, and was thanks to the efforts of the Cluster for Research into Coaching (CRiC) (see http://www.cheshire.mmu.ac.uk/cric/) and in its association with its academic journal Sports Coaching Review (http://www.tandfonline.com/loi/rspc20), published by Routledge. The approach to coaching examined by these pioneering scholars, practitioners and players is rather unique. Rather than assessing the role of a coach as a performance analyst from a quantitative lens or as a leader from a managerial perspective, this research group and its associates are chiefly concerned with the sociocultural study of coaching cultures, practices, policies and interventions through a critical approach to social theory. For this event, 30 papers, workshops and keynotes were delivered by participants mainly from all four nations of the UK, but also by delegates travelling from Brazil, Ireland and Norway - who were united by a concern improving coaching practices from that critical sociological perspective.

The term "coaching" clearly has broad connotations and potentiality for interdisciplinary study, and one of the themes, "pedagogy", enabled the organisation of a specialist stream on martial arts pedagogy. Following recent calls for the needs for more overtly methodological and pedagogical research in events such as the Martial Arts Studies Conference at the nearby Cardiff University (see my report on the $3^{\text {rd }}$ meeting in a recent issue of RAMA, Jennings, 2017), I called out to the wider field of scholars to add a different topic to the conventional team sports that seem to be the current focus in the sociology of coaching - in essence, to add to the diversity of what was already in the programme.

Martial arts are known for the myriad of styles, technique and methods that encompass this umbrella term, from the leaps and weaponry of Kalarippayattu to the drills and full-contact competitions seen in mixed martial arts (MMA), but are also varied in their pedagogy. Here, the use of the term "pedagogy" had a double meaning to describe both the ways of teaching and learning (pedagogies, in plural) and also the science of studying this (pedagogy, as a singular discipline). A recent small stream on "martial arts pedagogy" at the biannual international coaching conference at Cardiff Metropolitan University in the sporting city of Cardiff, Wales, expressed this complexity and variation. Amid keynotes and panels containing papers on an array of topics including the politics of sport coaching, trust among footballers and coaches and the preparation of elite Nordic athletes, four scholars interested in martial arts, combat sports and fighting systems were positioned around the two-day gathering. New PhD student Daniel Jacklin and I, George Jennings, of the host institution, offered talks on the first day and were later accompanied by researchers from the neighbouring University of South Wales (Lyn Jehu) and a closing plenary by renowned ethnographer Sara Delamont (Cardiff University). These four contributions raised questions and problems for martial arts instructors, promoters, practitioners and scholars to consider in future projects and debates, and I outline them here in chronological order for the martial arts community to peruse.

\section{The four papers: An overview of practice and pedagogy}

I have a background in various martial arts and come from a formation in exercise and sport science. My own research interests currently circulate around martial arts and health from an interdisciplinary approach that use philosophy, anthropology and sociology as well as an acknowledgement of the holistic views on health including and beyond the biomedical model (for example, see Jennings, 2014). Seeing the need to tackle health in its different guises, I advocated the need for a critical health pedagogy that adds to the advancement of knowledge aided by exploratory and descriptive studies thus far. I therefore suggested looking at both the 'light' and the 'dark' sides of martial arts in terms of their potential health benefits and dangerous drawbacks respectively. Based on my recent readings into praxeology (the philosophical study of practices) and praxiography (the analysis of practices) - particularly that of Girton's (1986) early study and 
the fresh perspective of Bueger (2014) - I advocated using practices as the basis unit of analysis for pedagogical research into martial arts. For me, these practices are composed of both 'techniques of the body' (to borrow a term from Marcel Mauss, 1934) and the exact methods used to drill, rehearse and test such techniques through people and specialist objects. Such practices can be healthy, harmful, holistic and hazardous, but should be judged by their individual components such as stepping, jumping, blocking, kicking and specific weapons training. This training could, as Zarrilli (1998) put it in relation to the complexity of the aforementioned Kalarippayattu, heal or harm.

The latter harmful practices were the focus of PhD student Daniel Jacklin's presentation. With a background as a Judo coach and training as a lawyer with a speciality in the leisure industry, Jacklin saw a strong case of athlete justice through the learned and often coerced practices that lead to rapid weight loss for competitor (and the accompanying rapid weight gain). These rapid fluctuations in body mass are very dangerous for health, and can have life threatening consequences. Jacklin shared the harrowing story of a 15-year-old Judoka from Eastern Europe whose case had actually inspired him to undertake the doctoral research project. This youth had gone through the severe measures of taking laxatives, vomiting, and extreme sweating to move up and down weight bands for competition. Jacklin warned how such practices are even more widespread with competition across combat sports, such as Judokas entering mixed martial arts competition. Within his first month of research, Jacklin has already outlined the strong case for exploring why athletes are following these practices, but also what can be done about it in the future.

The past was the main theme for Lyn Jehu's retrospective look at veteran Karate practitioner's tales of training in their youth. Jehu himself is a seasoned exponent and instructor of the art, and also possesses significant experience as a coach. Focusing on ten core members of a renowned Welsh Shotokan dojo, Jehu provided a perspective on his interview data using a theory from sport psychology: on mental toughness. This had already been utilised within a range of sports, but now it was adapted in a very different physical culture: the martial arts. Looking at the individual attributes of mental toughness, he adopted a culturally and linguistically sensitive approach by examining the Japanese concepts employed by this select group of men who are now senior instructors in Karate. Here, within a slightly orientalist understanding of "samurai" and "ancient" Japanese pedagogy, the practitioners reflected on their perceived need to train through injury and directly after recovery as part of the moral ethos of the Karate association. Adding a historical backdrop, Jehu explained the origins and recent transformations of Karate in the 1920s, which led to the later generations exporting the "Japanese" art to his home nation of Wales.

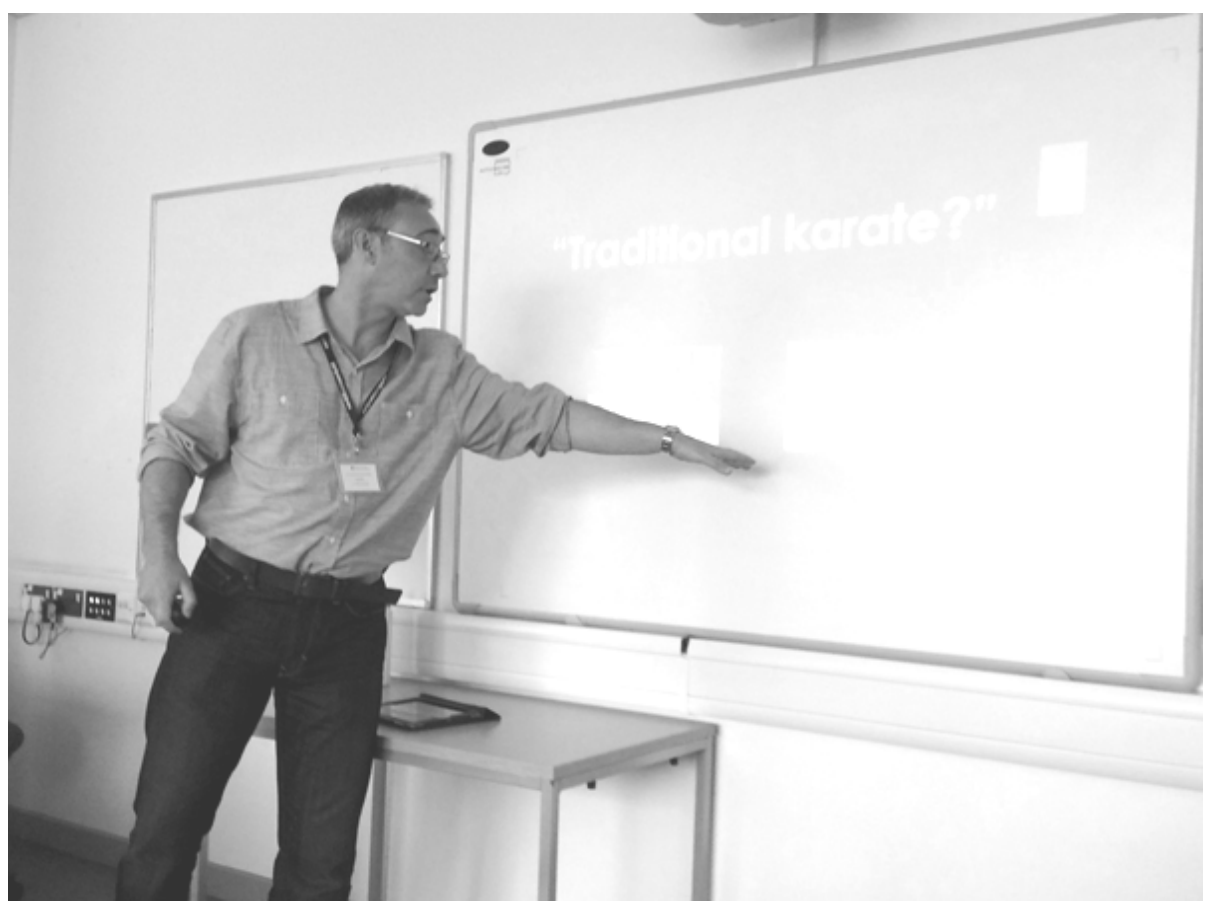

Picture 1. Lyn Jehu compares the pedagogy of Japanese and Okinawan Karate 
Impressed by the long and distinguished career of emeritus sociologist and ethnography, Sara Delamont, the organising committee graciously asked her to provide the closing plenary talk. Delamont has been observing (and now co-authoring with) James Southwood, a British teacher of the French art of Savate (also known as French boxing or French kickboxing), for five years. In her talk, she offered insights from these observations as well as a life history and discussions with various other exponents of the art - the tireurs. As specifically requested by the conference committee, Delamont shared her traditional ethnographic methods with the remaining delegates methods that were also utilised in her ten-year collaborative study of Capoeira that cultivated in her recent monograph (Delamont, Stephens, \& Campos, 2017): keeping separate field notes diary using coded script in one in order to avoid being understood by the participants and a reflexive journal in order to improve field notes, which support observations using all of the senses and in intuitive, interactive approach. Her methodological standpoint (Delamont, in press) is now being published using data extracts on Savate, and it is precisely such education examples that martial arts scholars may wish to produce and benefit from: the 'how' of pedagogy as a science and not just the 'what' of pedagogies as the object of study.

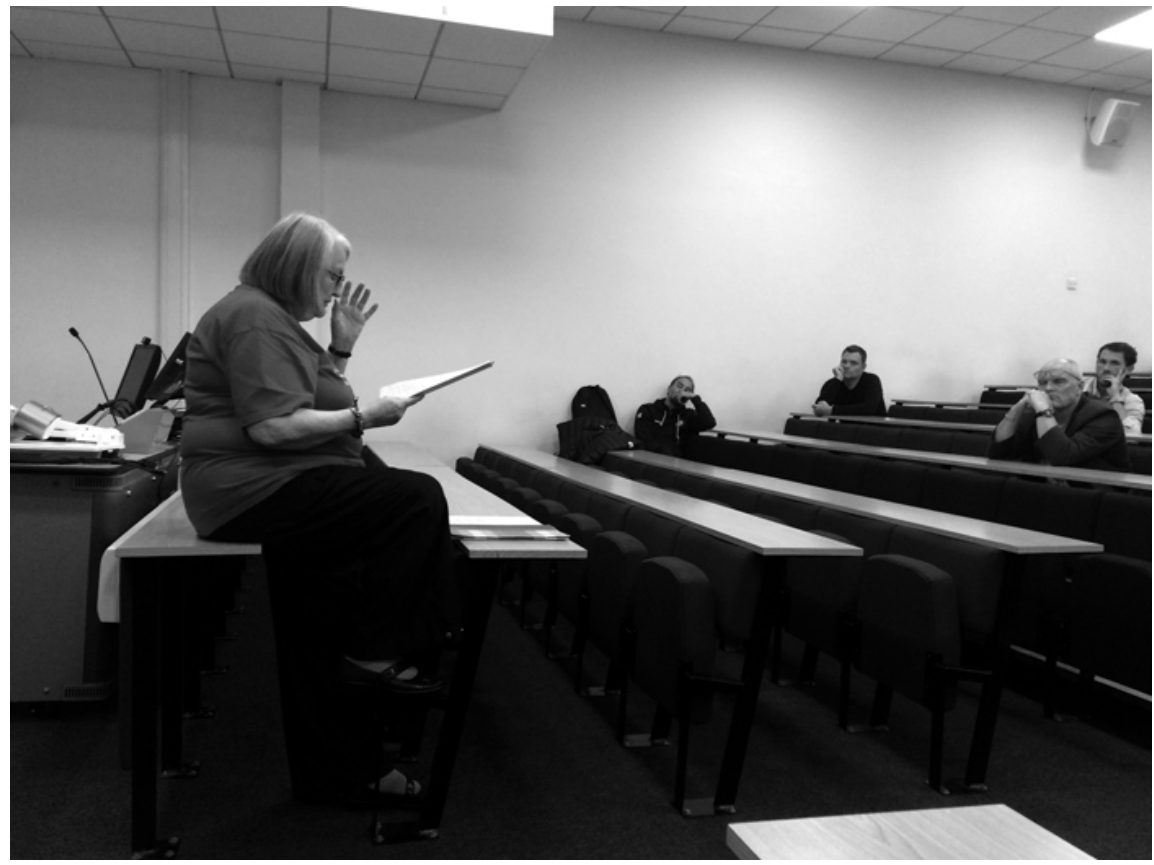

Picture 2. Sara Delamont durind her talk Tales of Tireur: Coaching tireur strategies of a UK savate teacher

\section{Future directions and dissemination}

The three twenty-minute conference papers and the more extensive, closing keynote are just the tip of the iceberg of martial arts pedagogical research that now spans several decades (for a review, refer to Channon \& Jennings, 2014). They are united by a stress on practices - be they techniques of the body, weight loss regimes, ways of conditioning the body or teaching strategies that are concerned with both teaching and learning. Martial arts scholarship can offer a great deal to coaching studies through the specialist knowledge of different cultures and philosophies, history and a variety of ways of using the body. At the same time, these studies could do well to work closely with physical educators, coaches and policy makers to examine how to improve practices in order for a safer, fairer and more sustainable way of engaging in martial arts: looking at the micro practices behind practices. There is much work to be done in bridging the seeming gulf between the worlds of coaching science, sport science and martial arts studies, but this gathering is one example of how researchers looking at fighting system can present their work and confer over common themes with their peers tackling issues in football, rugby and gymnastics.

It is an exciting time for such conferences to turn into collaborations. On an academic level, Cambridge University Press have contacted the conference convenors to produce a book of extended 1,000-word abstracts of a select number of the talks. This collection may even incorporate 
the biographies of the authors within the description of the study, to offer reflexive accounts and demonstrate innovation in writing. There is also plenty of scope for special collections and editions on martial arts pedagogies alone and in conjunction with those of other physical cultures. Meanwhile, local media such as DojoTV have galvanised on the opportunity to share the verbal messages of speakers to a wider audience (http://www.dojotv.co.uk/blog/is-martial-arts-good-foryou). These scholarly and public communications, when working in unison, can provide a stronger sense of the art and science of pedagogy with its numerous methods and theories as well as the multiplicity of opportunities when addressing the pedagogies and their embedded practices available to be studied.

\section{References}

Bueger, C. (2014). Pathways to practice: praxiography and international politics. European Political Science Review, 6(3), 383-406.

Channon, A., \& Jennings, G. (2014). Exploring Embodiment through Martial Arts and Combat Sports: A Review of Empirical Research, Sport in Society, 17(6), 773-789.

Cluster for Research into Coaching official website: http://www.cheshire.mmu.ac.uk/cric/ Last accessed 07.10.17.

Delamont, S. (in press). Fieldwork in education.

Delamont, S., \& Southwood, J. (2017). Tales of a tireur: Coaching strategies of a UK savate teacher. Paper presented at the $4^{\text {th }}$ International Coaching Conference, Cardiff Metropolitan University, 7th September, 2017.

Delamont, S., Stephens, N. \& Campos, C. (2017). Embodying Brazil: An ethnography of diasporic capoeira. London: Routledge.

DojoTV. Is martial arts good for you? http://www.dojotv.co.uk/blog/is-martial-arts-good-for-you Last accessed 07.10.17.

Jacklin, D. (2017). A study of athlete justice: The case of a Judoka's rapid weight loss practices. Paper presented at the $4^{\text {th }}$ International Coaching Conference, Cardiff Metropolitan University, $6^{\text {th }}$ September, 2017.

Jehu, L. (2017). Teaching methods in Japanese karate: Their influence on the perception of mental toughness attributes. Paper presented at the $4^{\text {th }}$ International Coaching Conference, Cardiff Metropolitan University, $7^{\text {th }}$ September, 2017.

Jennings, G. (2017a). Communicating martial arts knowledge: Conferring over a wealth of possibilities. Revista de Artes Marciales Asiáticas, 12(1), 45-49.

Jennings, G. (2017b). The 'light' and 'dark' side of martial arts pedagogy: Towards a study of (un)healthy practices. Paper presented at the $4^{\text {th }}$ International Coaching Conference, Cardiff Metropolitan University, $6^{\text {th }}$ September, 2017.

Jennings, G. (2015). Transmitting health philosophies through the traditionalist Chinese martial arts in the UK. Societies, (4), 712-736.

Mauss, M. (1968 [1934]). Techniques of the Body. Marcel Mauss, Sociologie et Anthropologie (with introduction by Claude Levi-Strauss), 4th edition (pp. 364-386). Paris: Presses Universitaires de France.

Sports Coaching Review official website: http://www.tandfonline.com/loi/rspc20 Last accessed 07.10.17.

Zarrilli, P.B. (1998). When the body becomes all eyes. New Delhi: Oxford University Press.

\section{Author's biographical data}

Dr. George Jennings is a lecturer in sport sociology / physical culture at the School of Sport and Health Sciences, Cardiff Metropolitan University, UK. He gained his PhD from the University of Exeter, where he conducted a sociological study of traditionalist Chinese martial arts as transformative practices before moving to Mexico to examine the emerging Mexican fighting systems from an anthropological perspective. George's work is chiefly concerned with martial arts cultures, pedagogies and philosophies, and he is currently examining the relationships between martial arts and health by calling for a unification of knowledge and methodological practices. He has also worked at St. Mary's University, London and at Abertay, Scotland. Email: gbjennings@cardiffmet.ac.uk 